\title{
Sclerosing bone dysplasia from 16th century Sardinia (Italy): a possible case of Camurati-Engelmann disease
}

\begin{tabular}{|c|c|}
\hline Journal: & International Journal of Osteoarchaeology \\
\hline Manuscript ID: & OA-14-0189.R2 \\
\hline Wiley - Manuscript type: & Research Article \\
\hline Date Submitted by the Author: & $n / a$ \\
\hline Complete List of Authors: & $\begin{array}{l}\text { Giuffra, Valentina; University of Pisa, Department of Translational Research } \\
\text { on New Technologies in Medicine and Surgery } \\
\text { Montella, Andrea; University of Sassari, Department of Biomedical Sciences } \\
\text { Bianucci, Raffaella; University of Turin, Department of Public Health and } \\
\text { Pediatric Sciences } \\
\text { Milanese, Marco; University of Sassari, Department of History, Human } \\
\text { Sciences and Education } \\
\text { Tognotti, Eugenia; University of Sassari, Department of Biomedical } \\
\text { Sciences } \\
\text { Caramella, Davide; University of Pisa, Department of Translational } \\
\text { Research on New Technologies in Medicine and Surgery } \\
\text { Fornaciari, Gino; University of Pisa, Department of Translational Research } \\
\text { on New Technologies in Medicine and Surgery } \\
\text { Bandiera, Pasquale; University of Sassari, Department of Biomedical } \\
\text { Sciences }\end{array}$ \\
\hline Keywords: & $\begin{array}{l}\text { Progressive diaphyseal dysplasia, cortical thickening, hyperostosis, } \\
\text { Alghero, Modern Age }\end{array}$ \\
\hline
\end{tabular}

\section{SCHOLARONE ${ }^{\text {Tw }}$}

Manuscripts 


\section{Sclerosing bone dysplasia from $16^{\text {th }}$ century Sardinia (Italy): a possible case of Camurati-Engelmann disease}

Giuffra Valentina ${ }^{1,2}$, Montella Andrea ${ }^{2}$, Bianucci Raffaella ${ }^{2,3,4,5}$, Milanese Marco ${ }^{2,6}$, Tognotti Eugenia $^{2}$, Caramella Davide ${ }^{7}$, Fornaciari Gino $^{1,2}$, Bandiera Pasquale $^{2}$

${ }^{1}$ Division of Paleopathology, Department of Translational Research on New Technologies in Medicine and Surgery, University of Pisa, Italy

${ }^{2}$ Center for Anthropological, Paleopathological and Historical Studies of the Sardinian and Mediterranean populations, Department of Biomedical Sciences, University of Sassari, Italy

${ }^{3}$ Laboratory of Physical Anthropology, Department of Public Health and Pediatric Sciences, University of Turin, Italy

${ }^{4}$ Centre for Ecological and Evolutionary Synthesis, Department of Biosciences, University of Oslo, Norway

${ }^{5}$ Anthropologie Bioculturelle, Droit, Ethique et Santé, Aix Marseille Université, Marseille, France

${ }^{6}$ Department of History, Human Sciences and Education, University of Sassari, Italy

${ }^{7}$ Division of Diagnostic and Interventional Radiology, Department of Translational Research on New Technologies in Medicine and Surgery, University of Pisa, Italy

\section{Corresponding author:}

Valentina Giuffra

Division of Paleopathology, Department of Translational Research on New Technologies in Medicine and Surgery, Via Roma 57, 56126 Pisa, Italy; E-mail: v.giuffra@med.unipi.it Tel.: 0039050 992894; fax: 0039050992706 
Running title: Sclerosing dysplasia from $16^{\text {th }}$ century Sardinia

Key words: Progressive diaphyseal dysplasia, cortical thickening, hyperostosisAlghero, Modern Age

Conflict of interest: all authors declare no conflict of interest

\section{Sponsor}

The research was funded by RAS Legge regionale 7 agosto 2007, n. 7, bando 2010 . 


\section{Abstract}

The skeletal remains of a male aged 45-55 years displaying several bone anomalies were unearthed from the Alghero (Sardinia) plague cemetery "lo Quarter", a burial site dating back to the 15821583 AD outbreak. The skeleton, whose stature is about $165 \mathrm{~cm}$, presents a bilateral hyperostosis with increased diameter of the diaphyses of all the long bones of the upper and lower limbs; the metaphyses appear to be involved, while the epiphyses are spared. Marked thickening of the cranial vault is also evident. Radiological study showed irregular cortical thickening and massive endoperiosteal bone apposition; sclerotic changes are observed in the diaphysis of some metacarpals. Computed Tomography (CT) cross sections of the long bones displayed a thickening of the cortical portion and endoperiosteal bone apposition.

The individual was affected by a sclerosing bone dysplasia, a genetic disease characterised by increased bone density. In differential diagnosis, several sclerosing bone dysplasia, such as hyperostosis corticalis generalisata, craniodiaphyseal dysplasia, craniometadiaphyseal dysplasia, pachydermoperiostosis, and Camurati-Engelmann disease, as well as other disorders characterized by sclerosing manifestations, such as Erdheim-Chester disease, mehloreostosis and skeletal fluorosis, need to be considered. The anomalies observed in skeleton 2179 fit with the features of Camurati-Engelmann disease, which is the most likely candidate for final diagnosis. It is highly challenging to evaluate how such a condition may have influenced the individual's lifestyle in terms of development, mobility and quality of life. This individual was probably symptomatic, and must have experienced common clinical symptoms, such as pain in the limbs and fatigability. However, the strong development of the muscular insertions and the degenerative changes in the upper limbs suggest that the mobility problems should not have prevented him from reaching a mature age and from performing essential daily activities.

The presented case is the unique paleopathological evidence of Camurati-Engelmann disease so far diagnosed. 


\section{Introduction}

Bone dysplasias are genetic diseases caused by disturbances in the process of endochondral or intramembranous bone formation and/or modelling. The large variety of anomalies, still relatively poorly understood, makes the diagnosis in clinical practice extremely challenging. The previous classification was based on clinical, radiological and morphological features, but the most recent progresses in the molecular pathogenesis of these disorders have allowed a classification based also on genetic criteria. The Nosology and Classification of Skeletal Disorders, 2010 revision (Warman et al., 2011), provided a list of 456 different conditions distributed in 40 groups; 316 of these conditions have been associated with a specific gene.

Osteopetrosis was the first sclerosing skeletal dysplasia to be described in 1904 and it is considered the prototype of this group of diseases. Progress in molecular studies ascertained that several other disorders, initially proposed as variant forms of osteopetrosis, are clinically and genetically distinct entities (Aggarwal, 2013).

In the 2010 classification the group characterised by increased bone density included 34 conditions, divided into three bone types of disorders: neonatal osteosclerotic dysplasias, increased bone density group (without modification of bone shape) and increased bone density group with metaphyseal and/or diaphyseal involvement (Warman et al., 2011). Disturbances in the pathways involved in osteoblast or osteoclast regulation are responsible for these hereditary sclerosing bone dysplasias, which lead to an abnormal accumulation of bone. Excessive bone deposition has a variable distribution and severity in the skeletal apparatus (Ihde et al., 2011).

The distinguishing features of the sclerosing bone dysplasias, which include a variety of distributions and radiographic appearances (Vanhoenacker et al., 2000), allow retrospective diagnoses in osteoarchaeological remains to be performed.

\section{Materials and methods}


The skeletal remains of ca 200 plague victims were unearthed from the courtyard of the former Jesuits' College in San Michele - Lo Quarter (Alghero, Sardinia) (Bianucci et al., 2012). The plague mass burial dates back to the epidemic that ravaged the town of Alghero in 1582-1583. Sixteen trenches, each containing the remains of 10 to 30 individuals, and 10 multiple graves, each containing an average number of 6 corpses, were identified (Milanese, 2010; Milanese, 2013). A skeleton (code number: 2179) exhumed from trench 4 (fig.1) showed several anomalies. An approach based on multiple lines of evidence was used, in order to achieve a broader paleopathological reconstruction of this individual.

The remains are not completely preserved, some bones being missed or fragmented (fig. 2). Sex determination was performed on the basis of the morphological features of the skull (Ferembach et al., 1977-79; Buikstra and Ubelaker, 1994). The age at death was determined on the basis of dental wear (Lovejoy, 1985), pubic symphysis surface morphology (Brooks and Suchey, 1990) and sternal rib end modification (Loth and Iscan, 1989). The stature was determined by using the formulas of Trotter and Gleser (1952). The study of entheses was performed following the standardised scoring method for robusticity developed by Mariotti et al. (2004; 2007). Degenerative joint disease of the limb joints and vertebrae was recorded in accordance with the methods and standards set out in the Global History of Health Project (Steckel et al., 2005).

Morphological macroscopic observation of the bones was followed by imaging study. A FCR Velocity by Fujy direct DR equipment was used for conventional X-rays, with the following parameters: 10-12 mAs with 54-60 keV, DFF $110 \mathrm{~cm}$. Computed Tomography (CT) was performed with a CT scanner Toshiba Aquilion 16, $120 \mathrm{kVp}, 100 \mathrm{~mA}$, slice thickness $1 \mathrm{~mm}$, DFOV $55.1 \times 40.00$

\section{Results}

Skeleton 2179 belongs to a mature male aged $45-55$ years, with a stature, based on the length of the radius and ulna, of about $165 \mathrm{~cm}$. 
Dentition is affected by intra-vitam tooth losses (maxillary right first premolar, first and second molar; mandibular right first, second and third molar, and left first and third molar), alveolar resorption and dental calculus. No caries were detected. Some teeth show root anomalies: the mandibular canines have double roots, and the maxillary left second molar has four roots; maxillary left and right second incisors are shovel-shaped.

Ligament and tendon insertion sites reveal a high degree of expression. Specifically, a marked development (grade 2-3) was observed at the insertion of the trapezoid ligament of the clavicles, triceps brachii of the left clavicle, pectoralis major of the humeri, deltoid of the right humerus, biceps brachii of the radii, pronator teres of the right radius, triceps brachii of the ulnae, supinator of the left ulna, gluteus maximus of the femora, iliopsoas of the left femur, soleus of the left tibia, and Achilles tendon of the right calcaneus. Enthesopathies were observed at the insertion of the conoid ligament of the clavicles, latissimus dorsi/teres major of the humeri, deltoid of the left humerus, interosseous membrane of the left radius, supinator of the right ulna.

Preserved joint surfaces showed osteoarthitic changes. More specifically, a grade 2 degenerative joint disease (slight marginal lipping (osteophytes less than about $3 \mathrm{~mm}$ ) and slight degenerative/productive changes present) was observed at the level of the acromial facet and glenoid cavity of the scapulae, proximal epiphysis of the right humerus, distal epiphysis of the left humerus, proximal and distal epiphysis of the right radius, distal epiphysis of the left radius, distal epiphysis of the ulnae, posterior surface of the patellae. A grade 3 degenerative joint disease (severe marginal lipping - osteophytes greater than about $3 \mathrm{~mm}$ ) and severe degenerative/productive changes present, with eburnation) was observed at the level of the acromial end of the clavicles and proximal epiphysis of the ulnae. The joints of the lower limbs are not evaluable since they have not been preserved. As for the spine, only the cervical and two thoracic vertebrae are preserved. The cervical vertebrae show osteoarthitic changes of the vertebral plates with marginal lipping and porosity; a bony bridge is present between $\mathrm{C} 6$ and $\mathrm{C} 7$ on the left side of the bodies. The two thoracic vertebrae show no osteoarthritic changes. 
At macroscopic observation a general thickening of several bones is observed. Although the skull bones are extremely fragmented and poorly preserved, a severe thickening can be appreciated (fig. 3a); the mandible is normal (fig. 3b). A hyperostosis of the diaphyses of the clavicles, humeri, ulnae, radii (fig. 4a-c), femora, tibiae and fibulae (fig. 5a-c), was bilaterally observed; the diaphyseal diameter appears to be increased compared to the long bones of a normal individual (figg. 4-5). The widening is extended to the metaphyseal region, whereas the epiphyses are normal. The surface of the long bones presents alterations, with periosteal reaction and bony spurs (fig. 6). At conventional X-rays, the upper (fig. 7a) and lower limbs (fig. 7b) appear widened and undermodeled, owing to an increased and irregular cortical thickening; massive endoperiosteal bone apposition is evident. The epiphyses of the left radius, ulna and humerus (the sole preserved) displays normal radiological appearance. At the level of the hands, sclerotic changes are observed in the diaphysis of the second, third and fourth metacarpals (fig. 8).

CT scans evidenced a marked thickening of the outer and inner cranial plates (fig. 9); cross sections of the long bones showed a thickening of the cortical portion and endoperiosteal bone apposition (fig. 10).

\section{Discussion}

\section{Differential diagnosis}

Skeleton 2179 from Alghero is affected by a sclerosing bone disease involving the skull and the diametaphyseal region of all the long bones symmetrically.

In differential diagnosis, several sclerosing bone dysplasias have to be considered, such as hyperostosis corticalis generalisata, craniodiaphyseal dysplasia, craniometadiaphyseal dysplasia, pachydermoperiostosis, and Camurati-Engelmann disease. Other disorders characterized by sclerosing manifestations, such as Erdheim-Chester disease, mehloreostosis and skeletal fluorosis, need to be discussed in differential diagnosis. 
Hyperostosis corticalis generalisata, also known as endosteal hyperostosis, is a rare autosomal recessive dysplasia first described in 1955 (Van Buchem et al., 1955), and comprises four main types, Van Buchem disease, Truswell-Hansen disease, Worth disease, and Nakamura disease (Ihde et al., 2011). Van Buchem disease shows an involvement of the cranial vault, mandible, ribs, clavicle and long bone diaphyses, with homogeneous endosteal cortical thickening and narrowed medullary canal, but asymmetrical enlargement of the mandible is one of its most relevant features. Truswell-Hansen disease is characterized by dense bones, as well as tall stature and syndactyly, which are not displayed by skeleton 2179; in Worth and Nakamura diseases facial abnormalities are present and there is no periosteal thickening (Vanhoenacker et al., 2003). These features allow to rule hyperostosis corticalis generalisata out.

Craniodiaphyseal dysplasia is a severe bone dysplasia with a poor prognosis first described by Halliday in 1949. The disorder is characterized by generalized hyperostosis and sclerosis, especially involving the skull and facial bones; the sclerosis is so severe that the resulting facial distortion is referred to as "leontiasis ossea" with progressive stenosis of craniofacial foramina. The diaphyses of the long bones show a cylindrical appearance with cortical thickening and narrowed medullary cavity. The ribs and clavicle are enlarged and the tubular bones of the hands and feet are also involved (Kaissi et al., 2012). The preserved facial bones and lower jaw of the skeleton from Alghero display no signs of leonine face; the mature age of this individual also speaks against this diagnosis.

Craniometadiaphyseal dysplasia was first reported by Schwarz in 1960 and is characterized by macrocephaly with frontal prominence and multiple wormian bones, dental hypoplasia, diaphyseal widening of the long tubular bones with undermineralized metaphyses in older individuals; the latter feature leads to increased bone fragility, widened ribs and clavicles, and broadening of the short tubular bones with thin cortices (Dhar et al., 2010). In the skeleton 2179 from Alghero neither dental hypoplasia nor fractures were identified and short tubular bones display normal/thickened cortex; therefore, craniometadiaphyseal dysplasia cannot be considered as a possible diagnosis. 
Pachydermoperiostosis, also named primary hypertrophic osteoarthropathy, is a rare disease affecting the skin and bones, first described by Friedreich in 1868, who defined the condition "hyperostosis of the entire skeleton". The form of inheritance has not yet been clarified. The bone involvement consists in a bulbous deformity of the third phalanges, known as digital clubbing, and periosteal proliferation of the long bone. Digital clubbing is the main feature of the disease, whereas the periostosis is progressive both in number of bones involved and in severity; in advanced cases all the tubular bones are affected, with involvement of the diaphyses, metaphyses and epiphyses (Martinez-Lavin, 2011). In the Alghero skeleton, the absence of alterations in the third phalanges and the sparing of epiphyses allow to exclude a late stage of pachydermoperiostosis.

Among the disorders of non-hereditary origin that can produce osteosclerosis Erdheim-Chester disease should be considered. It is a rare non-Langerhans cell histiocytosis of unknown etiology. The skeletal apparatus is affected, with symmetrical involvement of the diaphyses and metaphyses of the long bone, whereas the epiphyses, as well as the axial skeleton, hands and feet are spared. Cortical thickening with narrowing of medullary cavity is observed, and lytic lesions are possible (Mazor et al., 2013). In our case study, the involvement of the skull vault and metacarpals, as well as the absence of osteolytic foci rule out the Erdheim-Chester disease.

Melorheostosis is a rare benign sclerosing mesodermal dysplasia, affecting the skeleton and adjacent soft tissues. The characteristic radiological appearance consists of a dripping candle wax appearance of cortical and medullary hyperostosis. A single bone or multiple adjacent bones are affected, often in sclerotomal distribution. The lower limbs are more frequently involved than the upper limbs and the condition rarely involves the spine, skull and facial bones. Diaphyses and epiphyses are the favourite localisation. In skeleton 2179 the involvement of all long bones and skull, sparing of epiphyses and absence of the typical "drippling candle wax" appearance lead to exclude this diagnosis (Suresh et al., 2010).

Skeletal fluorosis is a chronic metabolic bone and joint disease caused by ingesting large amounts of fluoride either through water or rarely food of endemic areas. Fluoride is a cumulative toxin 
which can alter the accretion and resorption of bone tissue. It also affects the homeostasis of bone mineral metabolism. A combination of osteosclerosis, osteomalacia and osteoporosis of varying degrees as well as exostosis formation characterizes the bone lesions. The disease is characterized by immobilization of the joints of the axial skeleton and of the major joints of the extremities (Krishnamachari, 1986). The sparing of joints and the absence of osteoporosis and osteomalacia in skeleton 2179 allow to rule out skeletal fluorosis.

Camurati-Engelmann disease (CED), also known as progressive diaphyseal dysplasia, generalized hyperostosis and endostosis, congenital multiple hyperostotic disease, sclerosing dysplasia and symmetrical osteosclerosis, is a rare genetic disorder. The Nosology and Classification of Skeletal Disorders, 2010 revision (Warman et al., 2011), proposed to name this disorder as diaphyseal dysplasia Camurati-Engelmann.

CED was first described by Cockayne in 1920; the hereditary nature was suggested by Camurati in 1922, whereas Engelmann described the severe form of the disease. CED is an autosomal-dominant condition caused by mutations within the transforming growth factor- $\beta 1$ (TGF $\beta 1$ ) gene on chromosome 19q13 (Janssens et al., 2000); it is characterized by anomalies in intramembranous bone formation. The reported incidence of this disorder is one in 1,000,000 (Bhadada et al., 2014) and approximately 200 cases have been reported in the English literature so far (Jadhav \& Ghanekar, 2013). The onset of the disease is generally in childhood, but early manifestations starting from 3 months, or late ones in the sixth decade of life, have been recorded (Janssens et al., 2006).

The hallmark of the disorder is the thickening of the diaphyses of long bones, associated with sclerosis of the cranial vault. With progression of the disease, involvement of the metaphyses is possible, while the epiphyses are generally spared. The thickening of both the periosteal and endosteal portions result in a narrowing of the medullar cavity. The distribution of the skeletal anomalies is symmetrical and the most affected bones are the tibia, femur, fibula, humerus, ulna and 
radius; involvement of the mandible, clavicles, vertebrae, metacarpals and metatarsals is occasionally described (Bartuseviciene et al., 2009; Jadhav \& Ghanekar, 2013).

The anomalies observed in skeleton 2179 fit with the features of CED, which is the most likely candidate for final diagnosis (see Table 1). As a matter of fact, both the skull and the metadiaphyseal region of all tubular bones are involved with a marked hyperostosis and typical radiological appearance.

Since clinical studies evidenced a variable expressivity of clinical symptoms in patients affected by CED, it is highly challenging to evaluate how such condition may have influenced the individual's lifestyle in terms of development, mobility and quality of life. CED typically manifests in childhood, after attempts at walking, and physical retardation is common; these children start to walk at 3 to 4 years of age, they are pale, underweight, and manifest a weakness in the skeletal muscles. However, later in the course of the disease, their physical condition normalizes (Bartuseviciene et al., 2009). Pain in the extremities and muscle weakness are the most common clinical symptoms in adult age. Symptoms usually start with a dull bone ache, which intensified after physical exercise, even if severe pain is not common. In a review study carried out on 100 patients, pain in the extremities was observed in $68 \%$ of patients, and other clinical symptoms included peculiar waddling gait (48\%), easy fatigability (44\%), and muscle weakness (39\%); reduced subcutaneous fat (21\%) and hearing loss (15\%) were less common (Janssens et al., 2006). Asymptomatic patients, but with relatively minimal radiological changes, have also been described (Sparkes and Graham, 1972; Vanhoenacker et al., 2003).

\section{Behavioral Implications}

The analysis of entheseal changes and of degenerative joint disease of skeleton 2179 from Alghero can help reconstruct the life and physical activity of this individual, who was affected by this longterm and chronic condition. 
Entheseal changes showed a high development of muscular insertions. This pattern, however, cannot be exclusively interpreted as an evidence of marked physical activity. Recent studies have evidenced the limits and pitfalls of interpretations of entheseal changes as activity markers, mainly related to the problem of false positives (Jurmain et al., 2012; Villotte et al., 2013); in fact the main etiological factor of entheseal changes in studies carried out on skeletal samples with known age-atdeath is age (Milella et al., 2012).

Comparative data concerning entheseal development from other individuals from the same burial context may help address this question. Examination of the entheseal changes in the necropolis of Alghero evidenced a general trend, consisting of a major development of the muscular attachments in males than in females, and a progressive degree of expression related to age. In general, mature and senile males showed a marked development of the muscular insertion, more evident in the upper limbs. In our case study - a male aged between 45 and 55 years who was affected by a rare disease- it is highly likely that the marked muscular development is more an indicator of age rather than an expression of intense physical activity.

Similar considerations can be applied to the osteoarthritic changes observed in the upper limb joints of skeleton 2179 from Alghero. Direct links between specific activities and degenerative changes have been sought in archaeological samples, but the etiology of osteoarthritis is multifactorial, with age playing a major role in the onset and severity of the disease; recent studies have concluded that osteoarthritis is not a reliable direct indicator of physical activity and strain (Jurmain, 1999; Weiss \& Jurmain, 2007).

Nevertheless, the high development of the muscular insertions and the presence of grade 2 degenerative changes in the upper limbs suggest that this individual was not physically inactive and that, on the contrary, he carried out activities that involved muscular work.

The individual from Alghero shows an advanced stage of the disease, involving the skull and all the long bones; therefore, he should be symptomatic, since he is likely to have experienced the most common clinical symptoms, such as pain in the limbs and fatigability, and to have had an unusual 
gait. However, the mobility problems should not have prevented him from reaching a mature age and perhaps performing essential daily activities, such as to get up, walk brief distances and take charge of not demanding tasks.

\section{Conclusions}

Skeleton 2179 from Alghero is affected by hyperostosis of long bone diaphyses and metaphyses, associated with thickening of the cranial vault; the preserved epiphyses appear to have been spared. Differential diagnosis suggested a case of Camurati-Engelmann disease, a rare genetic condition with autosomic dominant transmission. An approximate 200 cases only have been reported in current clinical practice.

Sclerosing bone dysplasias are rare genetic diseases whose variety makes the clinical diagnosis challenging; in our case the mature age of the individual, with evident signs of late stage of the disease, helped us identifying the disorder. A few reports of sclerosing bone dysplasias, some of which doubtful and diagnosed in isolated bones (Nielsen \& Alexandersen, 1971; Nikolova et al., 2014), have been previously described in paleopathological literature (Urteaga \& Moseley, 1967;

Waldron et al., 1989). This makes the present case of particular interest, as it represents the unique paleopathological evidence of Camurati-Engelmann disease so far diagnosed.

\section{Acknowledgments}

We wish to thank Davide Giustini, Division of Diagnostic and Interventional Radiology, University of Pisa, for help in the radiological study, and Prof. Andrea Superti-Furga, Department of Medical and Surgical Pediatrics, University of Lausanne, for independent confirmation of the diagnosis. 


\section{References}

Aggarwal S. 2013. Skeletal dysplasias with increased bone density: evolution of molecular pathogenesis in the last century. Gene 528: 41-5.

Bartuseviciene A, Samuilis A, Skucas J. 2009. Camurati-Engelmann disease: imaging, clinical features and differential diagnosis. Skeletal Radiology 38:1037-43.

Bhadada SK, Sridhar S, Steenackers E, Dhiman V, Mortier G, Bhansali A, Van Hul W. 2014. Camurati-Engelmann disease (progressive diaphyseal dysplasia): reports of an Indian kindred. Calcif Tissue International 94: 240-7.

Bianucci R, Giuffra V, Ferroglio E, Milanese M, Fornaciari G. 2012. “Lo Quarter”: the Alghero plague cemetery (1582-1583 AD). Journal of Biological Research LXXXV: 212-214.

Brooks ST, Suchey JM. 1990. Skeletal age determination based on the os pubis: A comparison of the Acsadi-Nemeskeri and Suchey-Brooks methods. Human Evolution 5: 227-238.

Buikstra J, Ubelaker D. 1994. Standards for Data Collection from Human Skeletal Remains. Arkansas Archaeological Survey Research Series No. 44: Fayetteville.

Camurati M. 1922. Di un raro caso di osteite simmetrica ereditaria degli arti inferiori. La Chirurgia degli organi di movimento 6: 662-665.

Cockayne EA. 1920. Case for diagnosis. Proceedings of the Royal Society of Medicine 13: 132136.

Dhar SU, Taylor T, Trinh C, Sutton VR. 2010. Cranio-meta-diaphyseal dysplasia: 25 year followup and review of literature. American Journal of Medical Genetics. Part A 152A: 2335-2338.

Engelmann G. 1929. Ein fall von osteopathia hyperostotica (sclerostisans) multiplex infantilis. Fortschr Roentgenstr 39: 1101-1106

Ferembach D, Schwidetzky I, Stloukal M. 1977-79. Raccomandazioni per la determinazione dell'età e del sesso sullo scheletro. Rivista di Antropologia 60: 5-51.

Friedreich N. 1868. Hyperostose des gesammten skelettes. Virchows Archiv 43: 83-87. 
Halliday J. 1949. A rare case of bone dystrophy. British Journal of Surgery 37: 52-63

Ihde LL, Forrester DM, Gottsegen CJ, Masih S, Patel DB, Vachon LA, White EA, Matcuk GR Jr. 2011. Sclerosing bone dysplasias: review and differentiation from other causes of osteosclerosis. Radiographics 31: 1865-82.

Jadhav A, Ghanekar J. 2013. Camurati-Engelmann disease. Indian Journal of Clinical Practice 24: $171-174$

Janssens K, Gershoni-Baruch R, Van Hul E, Brik R, Guañabens N, Migone N, Verbruggen LA, Ralston SH, Bonduelle M, Van Maldergem L, Vanhoenacker F, Van Hul W. 2000. Localisation of the gene causing diaphyseal dysplasia Camurati-Engelmann to chromosome 19q13. Journal of Medical Genetics 37: 245-249.

Janssens K, Vanhoenacker F, Bonduelle M, Verbruggen L, Van Maldergem L, Ralston S, Guañabens N, Migone N, Wientroub S, Divizia MT, Bergmann C, Bennett C, Simsek S, Melançon S, Cundy T, Van Hul W. 2006. Camurati-Engelmann disease: review of the clinical, radiological, and molecular data of 24 families and implications for diagnosis and treatment. Journal of Medical Genetics 43: 1-11.

Jurmain R, Alves Cardoso F, Henderson CY, Villotte S. 2012. Bioarchaeology's Holy Grail: The Reconstruction of Activity. In: Grauer AL (Ed) A Companion to Paleopathology. New-York: Wiley-Blackell; 531-552.

Jurmain RD. 1999. Stories from the Skeleton. Behavioral Reconstruction in Human Osteology. London: Taylor and Francis.

Kaissi AA, Csepan R, Hofstaetter JG, Klaushofer K, Ganger R, Grill F. 2012. Fractures in connection with an atypical form of craniodiaphyseal dysplasia: case report of a boy and his mother. Clinics (Sao Paulo) 67: 1505-9. 
Krishnamachari KA. 1986. Skeletal fluorosis in humans: a review of recent progress in the understanding of the disease. Progress in Food \& Nutrition Science 10: 279-314.

Loth SR, Iscan MY. 1989. Morphological assessment of age in the adult: The thoracic region. In: Iscan MY, editor. Age Markers in the Human Skeleton. Charles C Thomas Pub: Springfield; 105135.

Lovejoy CO. 1985. Dental wear in the Libben population: its functional pattern and role in the determination of adult skeletal age at death. American Journal of Physical Anthropology 68: 47-56. Mariotti V, Facchini F, Belcastro MG. 2004. Enthesopathies - Proposal of a Standardized Scoring Method and Applications. Collegium Antropologicum 28: 145-159.

Mariotti V, Facchini F, Belcastro MG. 2007. The study of entheses: proposal of a standardised scoring method for twenty-three entheses of the postcranial skeleton. Collegium Antropologicum 31: 191-313.

Martinez-Lavin M. 2011. Miscellaneous non-inflammatory musculoskeletal conditions. Pachydermoperiostosis. Best Practice \& Research. Clinical Rheumatology 25: 727-34.

Mazor RD, Manevich-Mazor M, Shoenfeld Y. 2013. Erdheim-Chester Disease: a comprehensive review of the literature. Orphanet Journal of Rare Diseases 8: 137.

Milanese M, editor. 2010. Lo scavo del cimitero di San Michele ad Alghero (fine XIII - inizi XVII secolo). Felici Editore: Pisa.

Milanese M. 2013. Alghero. Archeologia di una città medievale, "Sardegna Medievale" 4. Carlo Delfino Editore: Sassari.

Milella M, Giovanna Belcastro M, Zollikofer CPE, Mariotti V. 2012. The effect of age, sex, and physical activity on entheseal morphology in a contemporary Italian skeletal collection. American Journal of Physical Anthropology 148: 379-388.

Nielsen OV, Alexandersen V. 1971. Malignant osteopetrosis in ancient Nubia. Danish Medical Bulletin 18: 125-128. 
Nikolova SY, Toneva DH, Yordanov YA, Lazarov NE. 2014. Multiple Wormian bones and their relation with definite pathological conditions in a case of an adult cranium. Anthropologischer Anzeiger 71: 169-90.

Schwarz E. 1960. Craniometaphyseal dysplasia. American Journal of Roentgenology 84: 461-466. Sparkes RS. Graham CB. 1972. Camurati-Engelmann disease. Genetics and clinical manifestations with a review of the literature. Journal of Medical Genetics 9: 73-85.

Steckel RH, Larsen C, Sciulli PW, Walker PL. 2005. The Global History of Health Project; Data Collection Codebook. Available at: http://global.sbs.ohio-state.edu.

Suresh S, Muthukumar T, Saifuddin A. 2010. Classical and unusual imaging appearances of melorheostosis. Clinical Radiology 8: 593-600.

Trotter M, Gleser GC. 1977. Corrigenda to "Estimation of Stature from Long Limb Bones of American Whites and Negroes" Am. J. Phys. Anthrop. (1952). American Journal of Physical Anthropology 47: 355-356.

Urteaga O, Moseley JE. 1967. Craniometaphyseal dysplasia (Pyle's disease) in an ancient skeleton from the Mochica culure of peru. American Journal of Physical Anthropology 99: 713-716.

Van Buchem FS, Hadders HN, Ubbens R. 1955. An uncommon familial systemic disease of the skeleton: hyperostosis corticalis generalisata familiaris. Acta Radiologica 44: 109-20.

Vanhoenacker FM, Balemans W, Tan GJ. 2003. Van Buchem disease: lifetime evolution of radioclinical features. Skeletal Radiology 32: 708-718.

Vanhoenacker FM, De Beuckeleer LH, Van Hul W, Balemans W, Tan GJ, Hill SC, De Schepper AM. 2000. Sclerosing bone dysplasias: genetic and radioclinical features. European Radiology 10: 1423-33.

Vanhoenacker FM, Janssens K, Van Hul W, Gershoni-Baruch R, Brik R, De Schepper AM. 2003. Camurati-Engelmann disease: review of radioclinical features. Acta Radiologica 44: 1-5.

Villotte S. Knüsel CJ. 2013. Understanding entheseal changes: definition and life courses changes. International Journal of Osteoarchaeology 23: 135-146. 
Waldron T, Cox M, Molleson T. 1989. Osteopetrosis in an eighteenth century English family. Paper presented at the $16^{\text {th }}$ Annual Meeting of the Paleopathology Association held in San Diego, CA on 4-5 April, 1989. Paleopathology Newsletter 66 (June, Suppl): 4.

Warman ML, Cormier-Daire V, Hall C, Krakow D, Lachman R, LeMerrer M, Mortier G, Mundlos

S, Nishimura G, Rimoin DL, Robertson S, Savarirayan R, Sillence D, Spranger J, Unger S, Zabel B, Superti-Furga A. 2011. Nosology and classification of genetic skeletal disorders: 2010 revision. American Journal of Medical Genetics. Part A. 155A: 943-68.

Weiss E, Jurmain R. 2007. Osteoarthritis revisited: a contemporary review of aetiology. International Journal of Osteoarchaeology 17: 437-450.

\section{Legend to the figures}

Figure 1 Skeleton 2179 in trench 4 from the Alghero plague cemetery (1582-1583 AD)

Figure 2 State of preservation of skeleton 2179

Figure 3 Fragment of the right parietal and temporal bones; see thickening in detail (upper left) (a); the mandible (b)

Figure 4 Anterior view of the left humerus of skeleton 2179 (left) compared to a normal humerus of a male individual of similar age from the same burial site (US 5125) (right) (a); anterior view of the left ulna of skeleton 2179 (left) compared to a normal ulna (US 5125) (right) (b); posterior view of the left radius of skeleton 2179 (left) compared to a normal radius (US 5125) (right) (c) 
Figure 5 Posterior view of the left femur of skeleton 2179 (left) compared to a normal femur (US 5125) (right) (a); anterior view of the left tibia and fibula of skeleton 2179 (left) compared to a normal tibia and fibula (US 5125) (right) (b)

Figure 6 Detail of the surface of left femur (a) and right fibula (b) with periosteal changes Figure 7 AP projection of left humerus, radius and ulna, which evidences irregular cortical thickening (a); AP projection of left femur, tibia and fibula with the same features of upper limbs (b)

Figure 8 AP projection of hands revealing cortical thickening in the diaphysis of the second, third and fourth metacarpals

Figure $9 \mathrm{CT}$ cross section of the skull that shows thickening of the cranial vault Figure 10 CT cross section of the left humerus of US 2179 (left) compared to the normal humerus of US 2125 (right) in correspondence of the lower half of the diaphysis (a); CT cross section of the left ulna of US 2179 (left) compared to the normal ulna of US 2125 (right) in correspondence of the upper half of the diaphysis (b); CT cross section of the left radius of US 2179 (left) compared to the normal radius of US 2125 (right) in correspondence of the central diaphysis (c); CT cross section of the left femur of US 2179 (left) compared to the normal femur of US 2125 (right) in correspondence of the central diaphysis (d); CT cross section of the left tibia of US 2179 (left) compared to the normal tibia of US 2125 (right) in correspondence of the lower half of the diaphysis (e); CT cross section of the left fibula of US 2179 (left) compared to the normal fibula of US 2125 (right) in correspondence of the lower half of the diaphysis (f). The long bone are oriented facing down the posterior side. Both periosteal and endosteal bone thickening is evident 


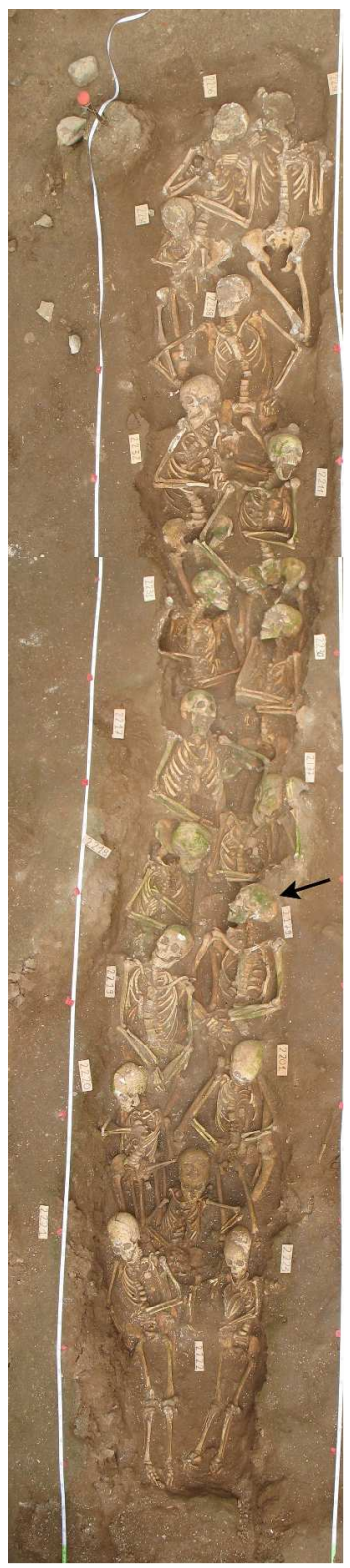

Skeleton 2179 in trench 4 from the Alghero plague cemetery (1582-1583 AD) $356 \times 1647 \mathrm{~mm}(72 \times 72$ DPI $)$ 

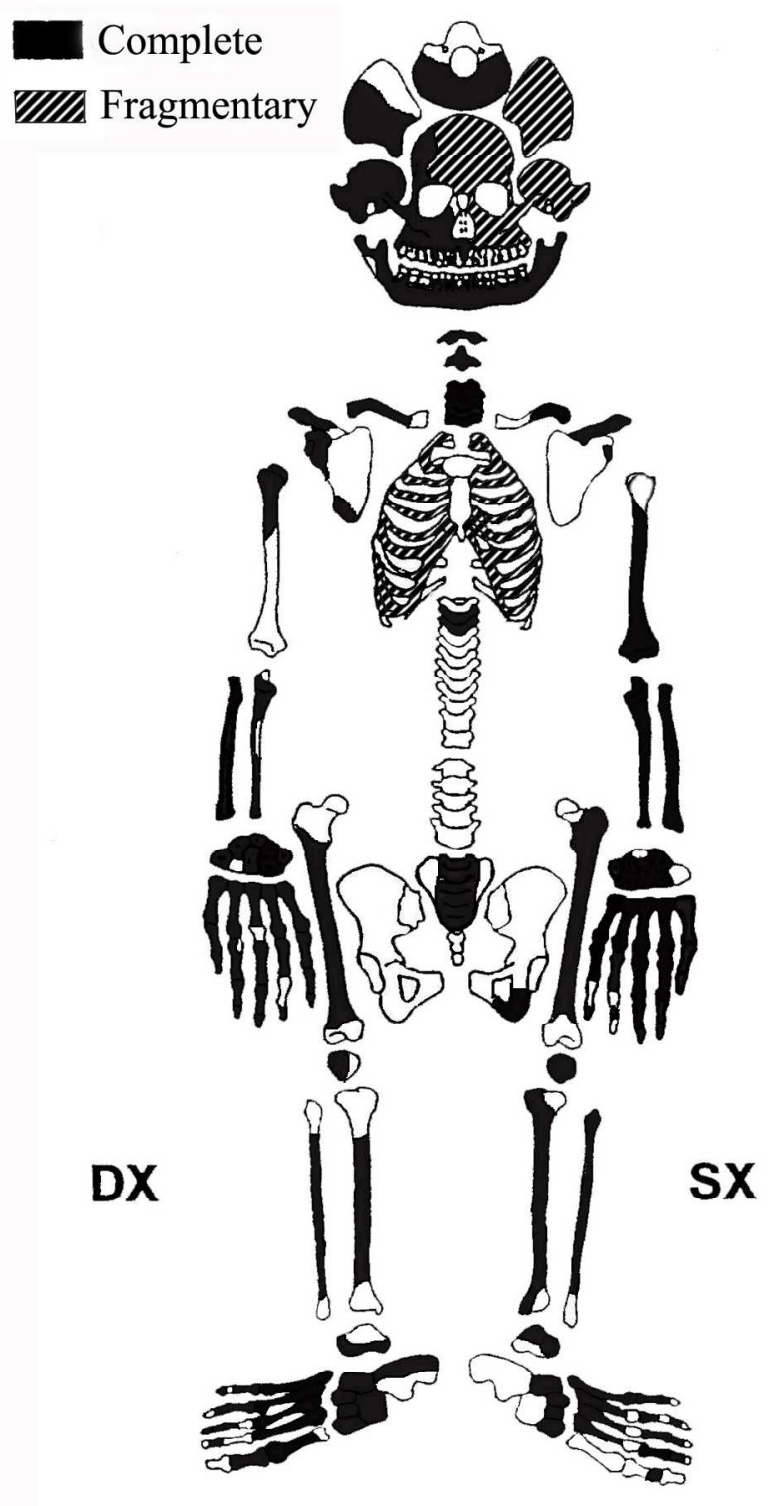

State of preservation of skeleton 2179 

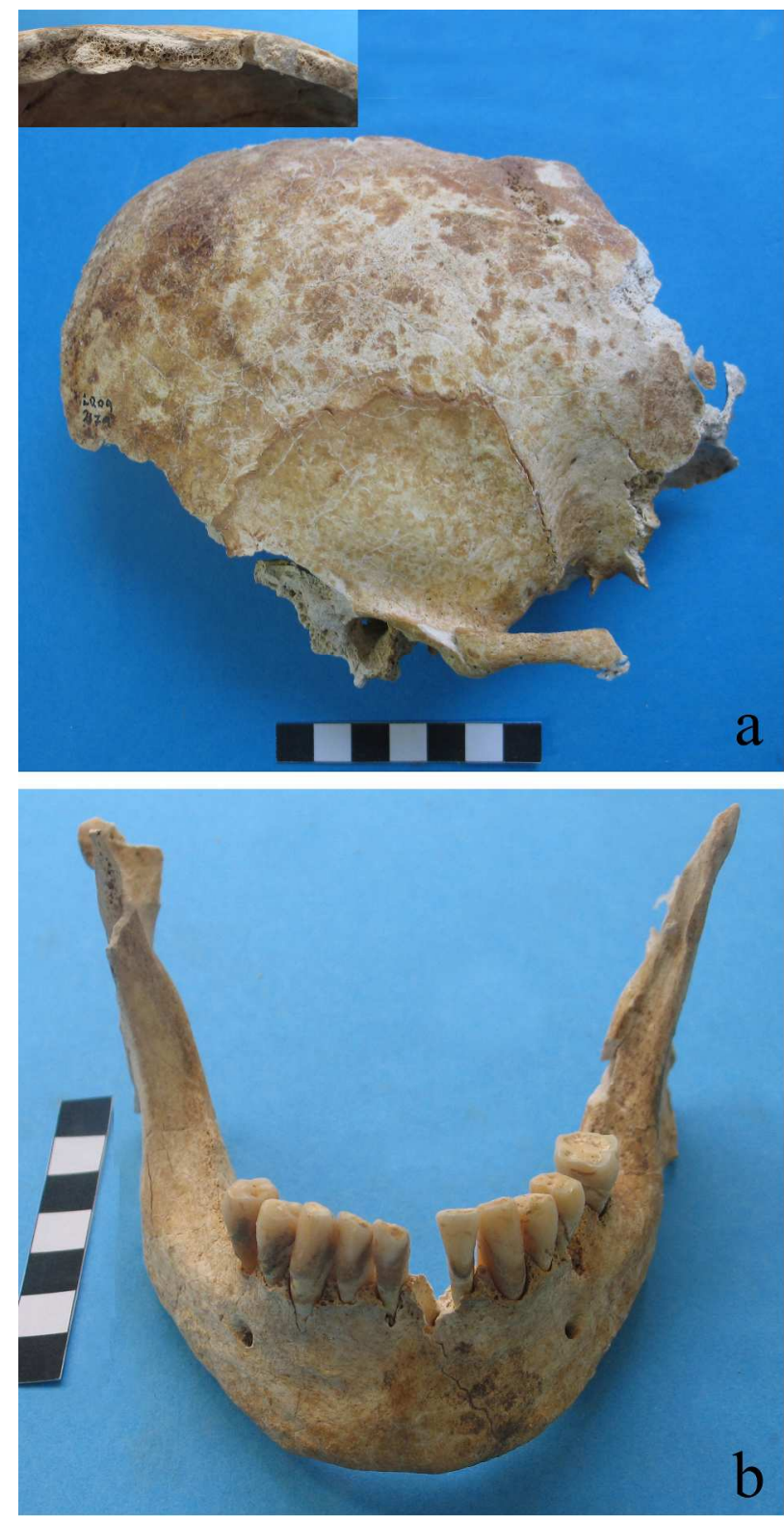

Fragment of the right parietal and temporal bone; in the detail (upper left) the thickening can be appreciated (a); the mandible (b) 

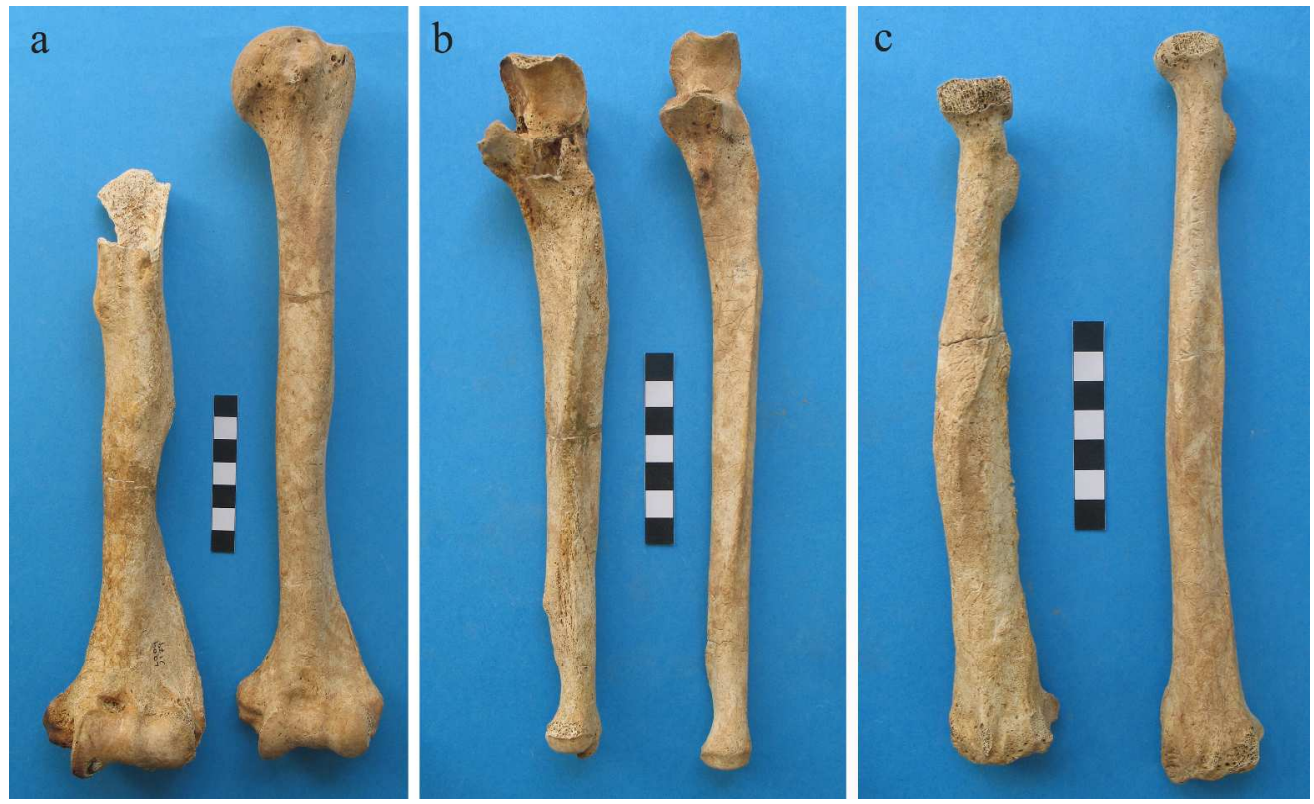

Anterior view of the left humerus of skeleton 2179 (left) compared to a normal humerus of a male individual of similar age at death from the same burial site (US 5125) (right) (a); anterior view of the left ulna of skeleton 2179 (left) compared to a normal ulna (US 5125) (right) (b); posterior view of the left radius of skeleton 2179 (left) compared to a normal radius (US 5125) (right) (c) $374 \times 228 \mathrm{~mm}(300 \times 300 \mathrm{DPI})$ 

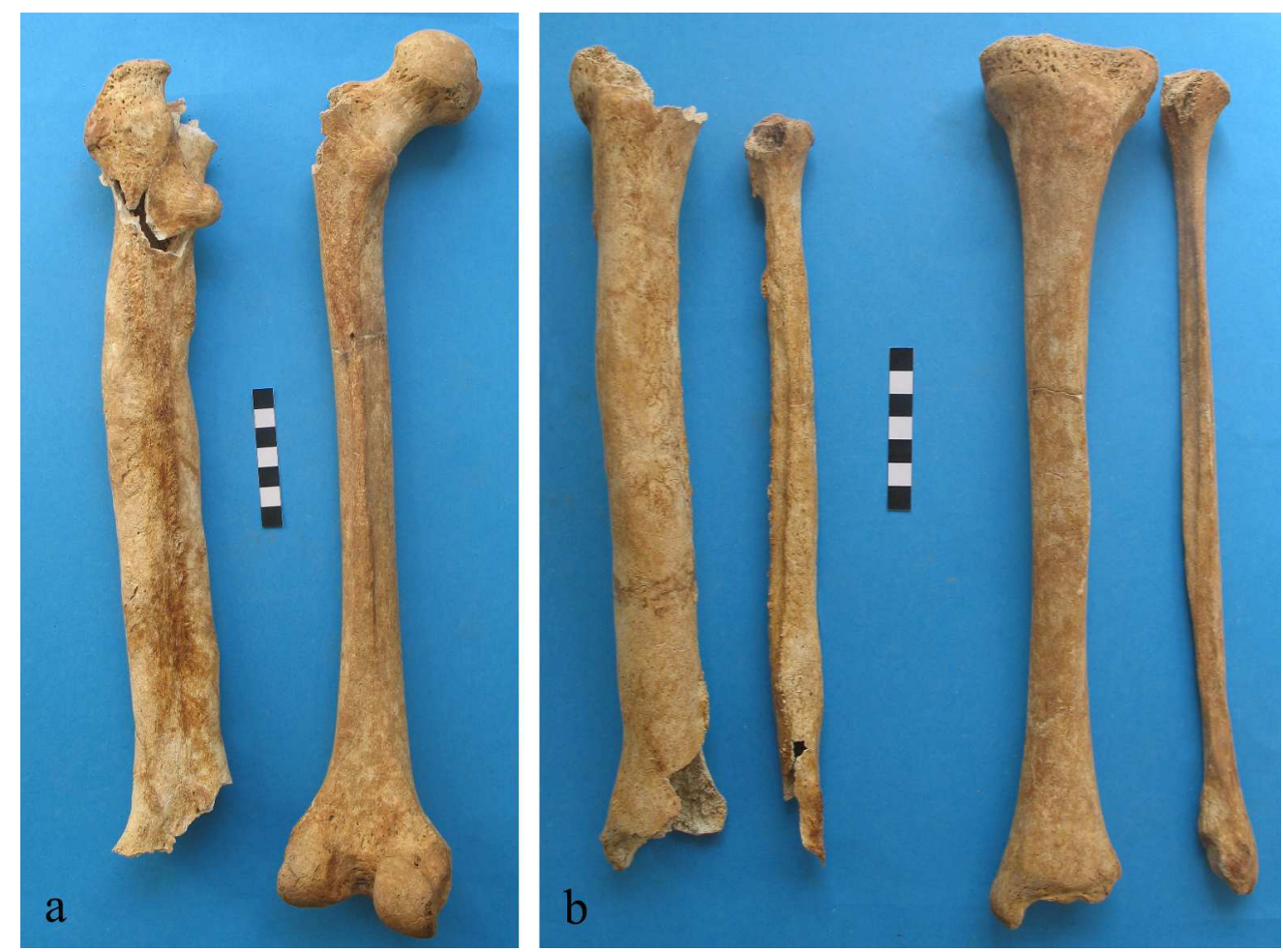

Posterior view of the left femur of skeleton 2179 (left) compared to a normal femur (US 5125) (right) (a); anterior view of the left tibia and fibula of skeleton 2179 (left) compared to a normal tibia and fibula (US 5125) (right) (b) $319 \times 236 \mathrm{~mm}(300 \times 300 \mathrm{DPI})$ 

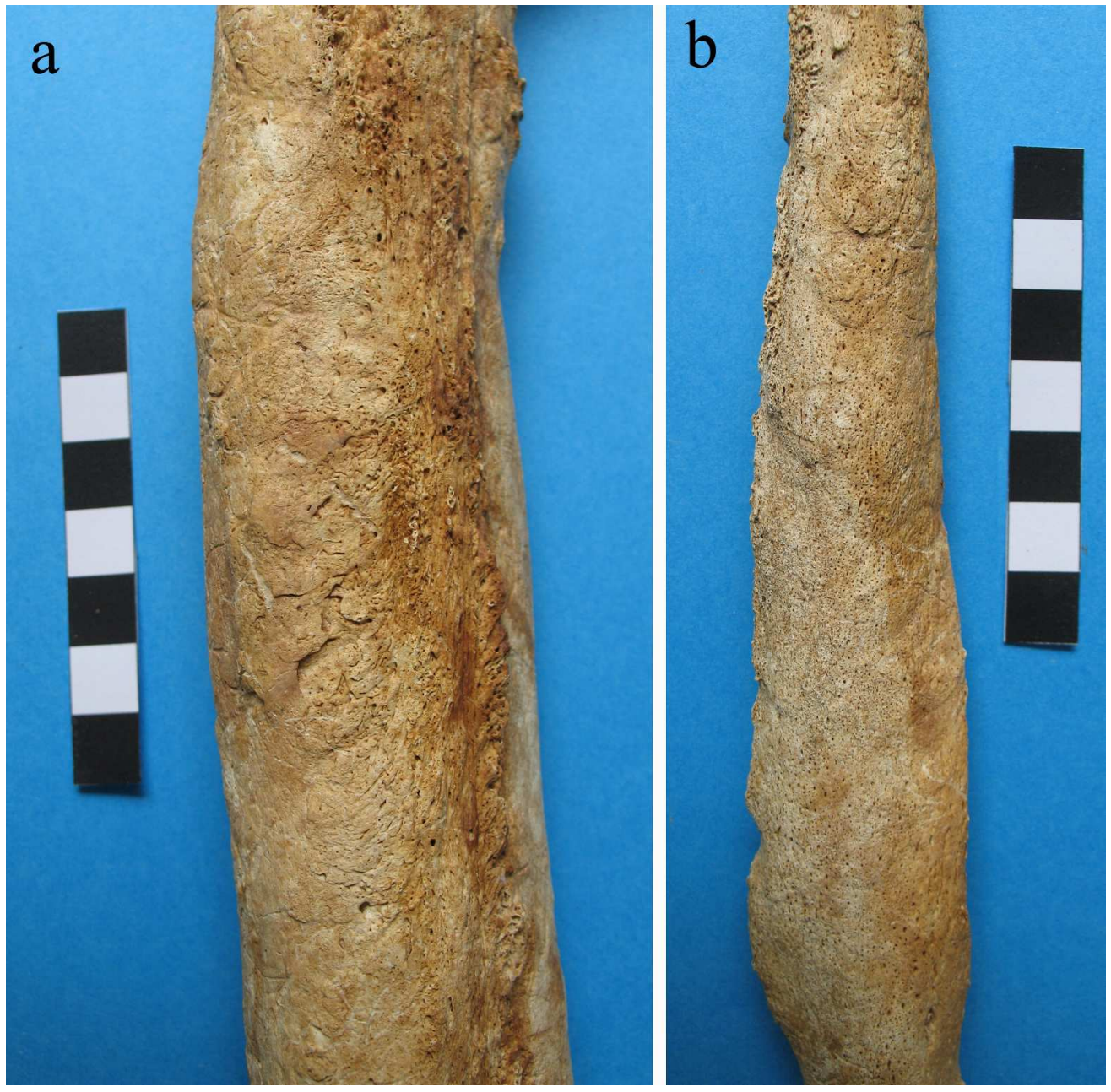

Detail of the surface of left femur (a) and right fibula (b) with periostitic changes 

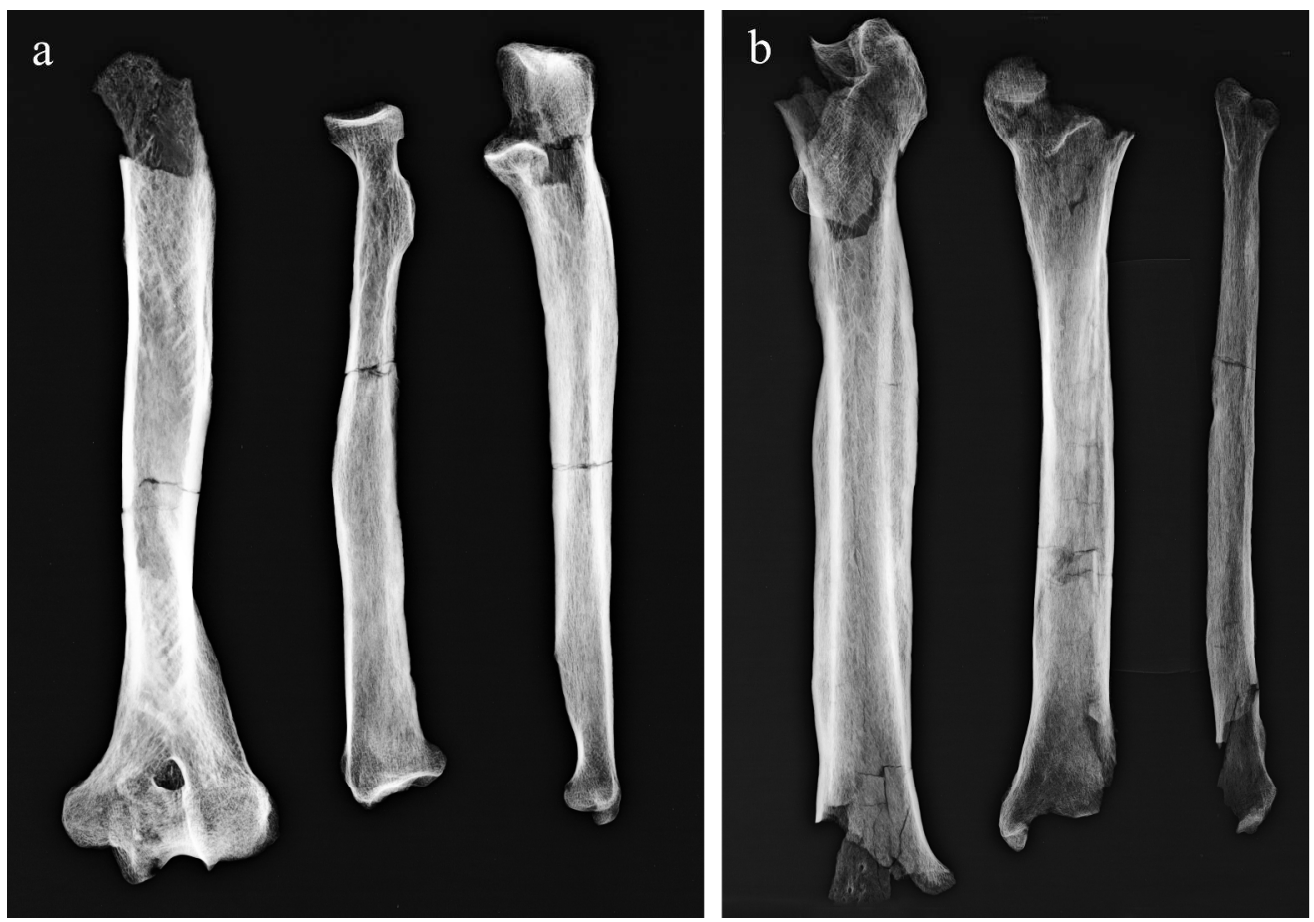

AP projection of left humerus, radius and ulna, which evidences irregular cortical thickening (a); AP projection of left femur, tibia and fibula with the same features of upper limbs (b) $1130 \times 786 \mathrm{~mm}(100 \times 100$ DPI $)$ 


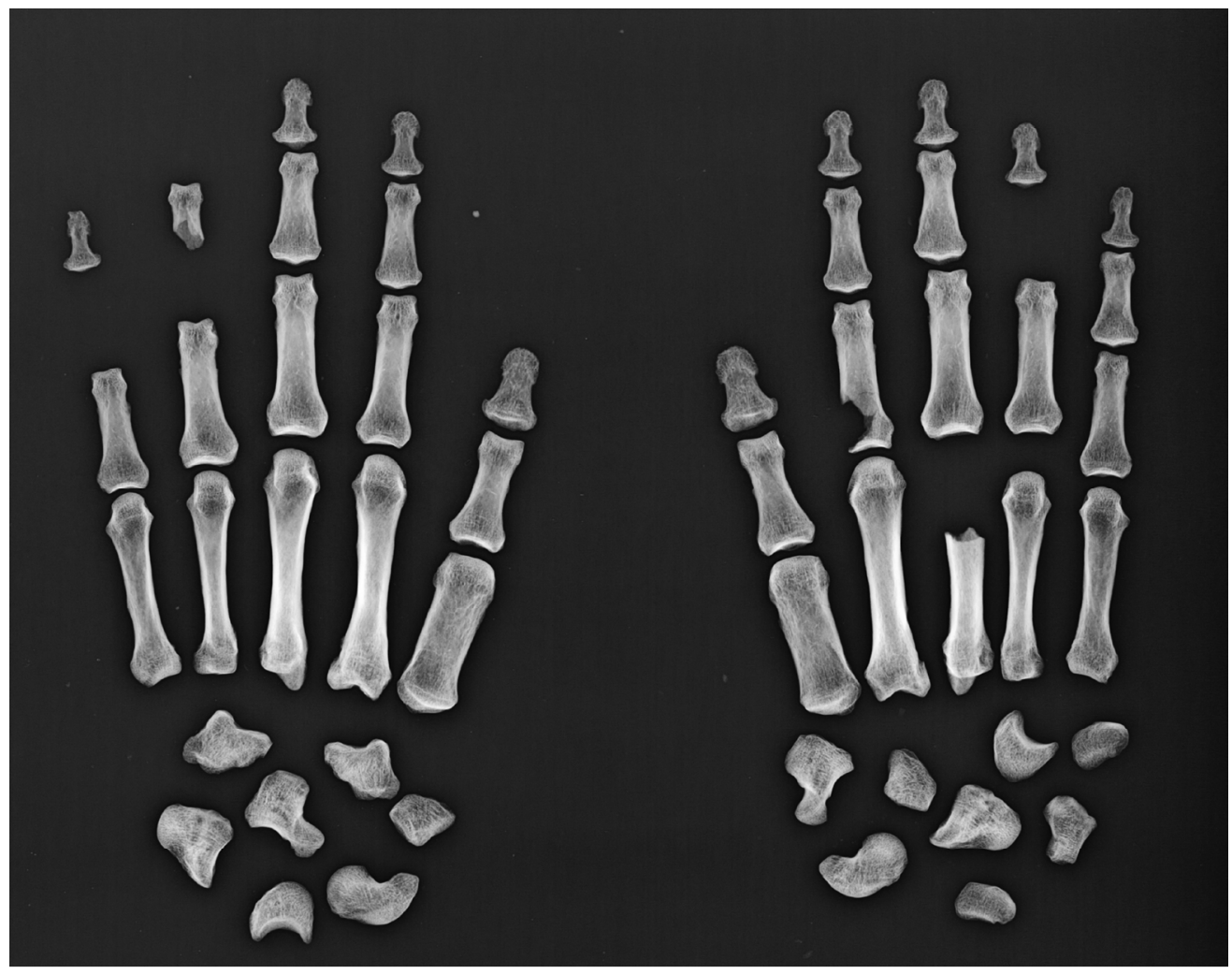

AP projection of hands revealing cortical thickening in the diaphysis of the second, third and fourth metacarpals $300 \times 235 \mathrm{~mm}(150 \times 150 \mathrm{DPI})$ 


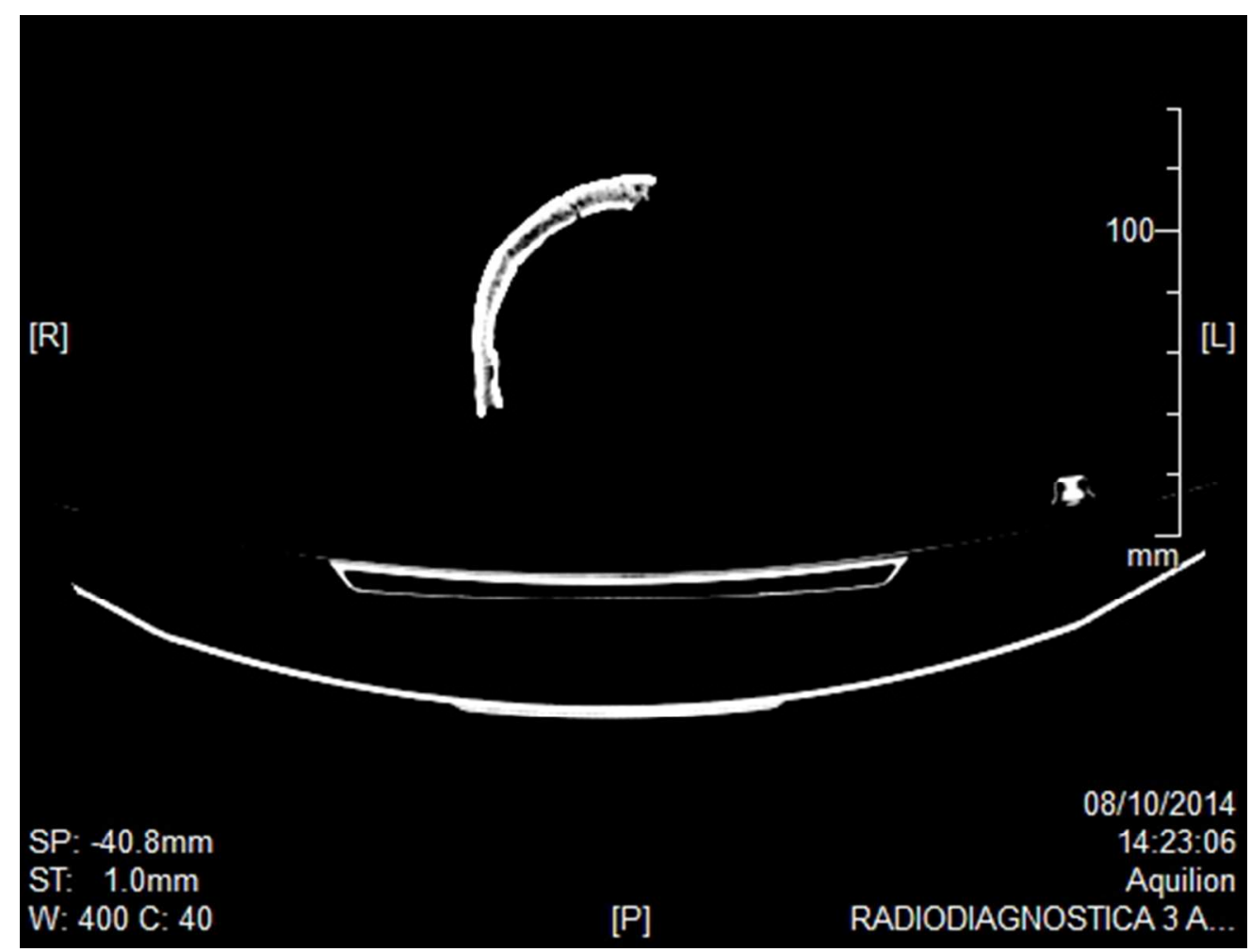

$\mathrm{CT}$ cross section of the skull that shows thickening of the cranial vault 

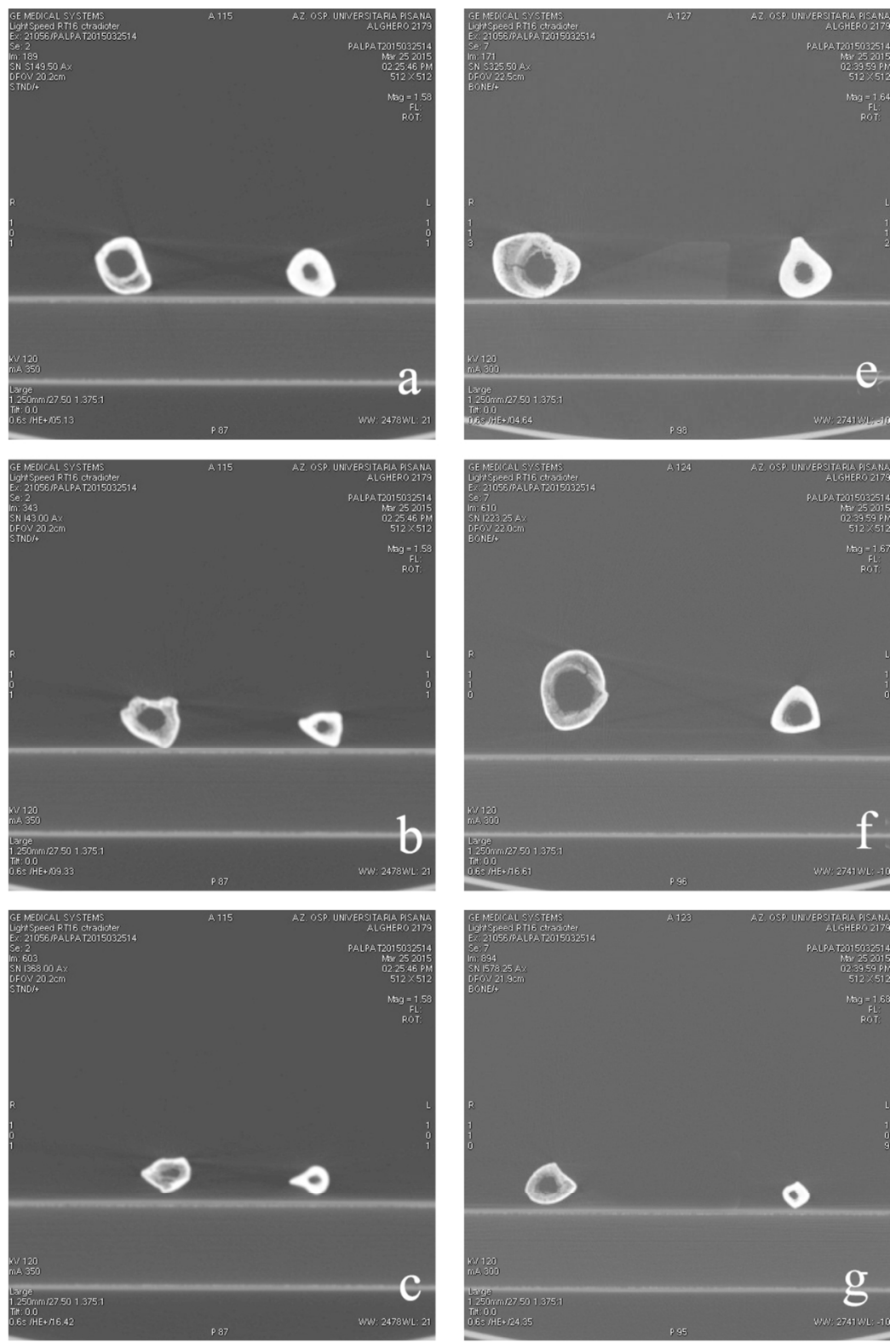

CT cross section of the left humerus (left) compared to the normal humerus of US 2125 (right) in correspondence of the lower half of the diaphysis (a); CT cross section of the left ulna (left) compared to the normal ulna of US 2125 (right) in correspondence of the upper half of the diaphysis (b); CT cross section of the left radius (left) compared to the normal radius of US 2125 (right) in correspondence of the central diaphysis (c); CT cross section of the left femur (left) compared to the normal femur of US 2125 (right) in correspondence of the central diaphysis (d); CT cross section of the left tibia (left) compared to the normal tibia of US 2125 (right) in correspondence of the lower half of the diaphysis (e); CT cross section of the left fibula (left) compared to the normal fibula of US 2125 (right) in correspondence of the lower half of the diaphysis (f). The long bone are oriented facing down the posterior side. Thickening of both the periosteal and endosteal portions of the bones with narrowing of medullary cavity is evident $52 \times 79 \mathrm{~mm}(600 \times 600 \mathrm{DPI})$ 


\begin{tabular}{|c|c|c|c|c|c|c|c|c|c|c|c|}
\hline & $\begin{array}{l}\text { Van } \\
\text { Buchem } \\
\text { disease } \\
\end{array}$ & $\begin{array}{l}\text { Truswell- } \\
\text { Hansen } \\
\text { disease }\end{array}$ & $\begin{array}{l}\text { Worth } \\
\text { disease }\end{array}$ & $\begin{array}{l}\text { Nakamura } \\
\text { disease }\end{array}$ & $\begin{array}{l}\text { Craniodiaphyseal } \\
\text { dysplasia }\end{array}$ & $\begin{array}{l}\text { Craniometadiap } \\
\text { hyseal dysplasia }\end{array}$ & $\begin{array}{l}\text { Pachydermo } \\
\text { periostosis }\end{array}$ & $\begin{array}{l}\text { Camurati- } \\
\text { Engelmann } \\
\text { disease }\end{array}$ & $\begin{array}{l}\text { Erdheim- } \\
\text { Chester } \\
\text { disease }\end{array}$ & $\begin{array}{l}\text { Melorheost } \\
\text { osis }\end{array}$ & $\begin{array}{l}\text { Endemic } \\
\text { skeletal } \\
\text { fluorosis }\end{array}$ \\
\hline $\begin{array}{l}\text { Cranial } \\
\text { thickening }\end{array}$ & $\mathbf{P}$ & $\mathbf{P}$ & $\mathbf{P}$ & $\mathbf{P}$ & $\mathbf{P}$ & $\mathbf{P}$ & A & $\mathbf{P}$ & $\mathrm{A}$ & A & $\mathrm{A}$ \\
\hline $\begin{array}{l}\text { Normal } \\
\text { facial bones }\end{array}$ & $\mathrm{A}$ & A & $\mathrm{A}$ & $\mathrm{A}$ & A & A & A & $\mathbf{P}$ & $\mathbf{P}$ & $\mathbf{P}$ & $\mathbf{P}$ \\
\hline $\begin{array}{l}\text { Normal } \\
\text { mandible }\end{array}$ & A & A & A & A & A & A & A & $\mathbf{P}$ & $\mathbf{P}$ & $\mathbf{P}$ & $\mathbf{P}$ \\
\hline $\begin{array}{l}\text { Diaphyseal } \\
\text { hyperostosis }\end{array}$ & $\mathbf{P}$ & $\mathbf{P}$ & A & A & $\mathbf{P}$ & $\mathbf{P}$ & $\mathbf{P}$ & $\mathbf{P}$ & $\mathbf{P}$ & $\mathbf{P}$ & $\mathbf{P}$ \\
\hline $\begin{array}{l}\text { Metaphyseal } \\
\text { hyperostosis }\end{array}$ & $\mathbf{P}$ & $\mathbf{P}$ & A & A & A & $\mathbf{P}$ & $\mathbf{P}$ & $\mathbf{P}$ & $\mathbf{P}$ & A & $\mathbf{P}$ \\
\hline $\begin{array}{l}\text { Normal } \\
\text { epiphyses }\end{array}$ & $\mathbf{P}$ & $\mathbf{P}$ & $\mathbf{P}$ & $\mathbf{P}$ & $\mathbf{P}$ & $\mathbf{P}$ & A & $\mathbf{P}$ & $\mathbf{P}$ & $\mathrm{A}$ & $\mathrm{A}$ \\
\hline
\end{tabular}

Table 1 Bone lesions observed in skeleton 2179 from Alghero compared to the expectations of each diagnostic option evaluated in the differential diagnosis. Legend: $\mathrm{P}=$ present; $\mathrm{A}=$ absent 